Archaeological Journal

\title{
Dunster Castle
}

\section{G. T. Clark F.S.A.}

To cite this article: G. T. Clark F.S.A. (1879) Dunster Castle, Archaeological Journal, 36:1, 309-320, DOI: $10.1080 / 00665983.1879 .10851884$

To link to this article: http://dx.doi.org/10.1080/00665983.1879.10851884

$$
\text { 曲 Published online: 14 Jul } 2014 .
$$

Submit your article to this journal ๔

Q View related articles $₫$ 
DUNSTER CASTLE.

Scale 3 Chains - 1 Inch.

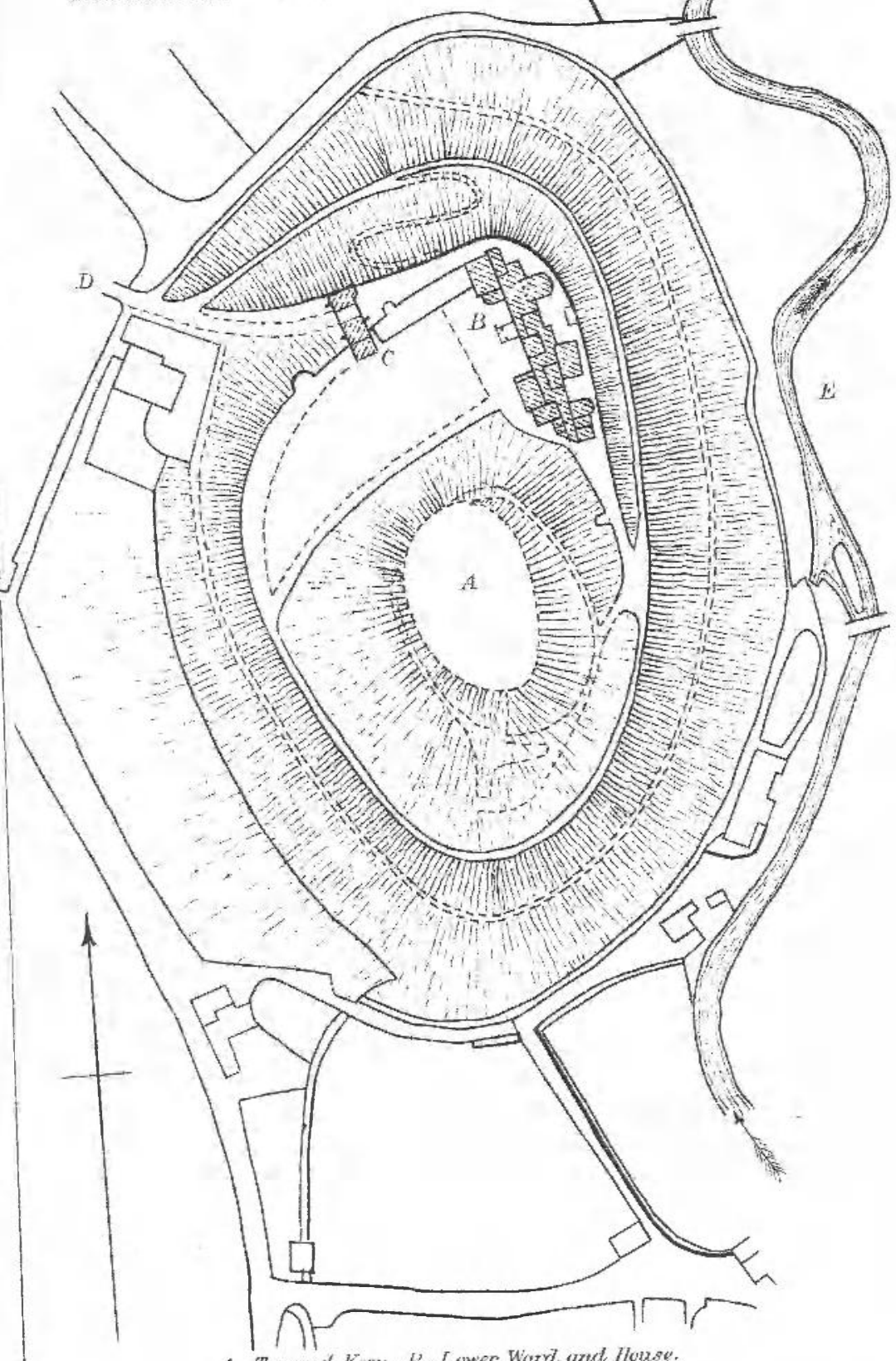

A. Tor and Keep. B. Lower Ward. arud Honse.

C. Arucient Fintrance and later Gatehouse: The Park. 


\title{
Arrbaeologiaal In ourual.
}

\author{
DECEMBER, 1879.
}

DUNSTER CASTLE.

By G. T. CLARK, F.S.A.

The Castle of Dunster is of high antiquity, and for many centuries was a place of great military consideration in the western counties. It was the caput of an extensive Honour, and the chief seat of a line of very powerful barons. The hill upon which it stands is the northeastern, or seaward extremity of a considerable ridge, from which it is cut off by a natural depression, and thus forms what was known in west Saxon nomenclature as a tor. The tor covers above ten acres of ground, and is about $200 \mathrm{ft}$. high, with a table top in area about a quarter of an acre. It stands upon the western edge of a deep and broad valley, which contains the park, and below the castle expands into a tract of meadow about a mile in breadth, and which skirts the sea from Minehead to below Carhampton. The park is traversed by a considerable stream, the Avill, one head of which springs from Croydon Hill, and the other, flowing past WottonCourtenay, rises about six miles distant under Dunkery Beacon. The home view, one of exceeding richness, is limited and sheltered on the south and west by the Brendon Hills and the high ground rising towards Exmoor. To the east it includes the vales of Cleeve and Williton bounded by the Quantocks. Seaward on to the north the eye ranges over Bridgwater Bay to the headland of Brean Down and Worle, and commands the west or opposite coast from Penarth Point to Aberavan and Swansea. 
West, and at the foot of the castle hill, and under the immediate control and protection of the old fortress, is the town of Dunster, a small but compact cluster of old fashioned houses, many with timber fronts, in the midst of which is the parish church, once connected with the priory, the foundation of one of the early Norman lords. The eastern or monastic part of the building now forms the private chapel of the Luttrells, and contains several of their tombs. The fancy cloths once known as "Dunsters" have long ceased to be fabricated, and of the fulling mills the ruins have well nigh perished. The haven at which these manufactures fiound shipping is also silted up, and the privileges conceded to the townspeople, being now shared by the community at large, are no longer commemorated, and are known only because the charters granting them have been preserved. Of the neighbouring hills "Gallocks" is thought to be so called because there the high judicial powers of the lords were exercised in the view of all men, and "Grabhurst," the castle ridge, is said to be named from an entrenched wood, though this use of the word 'graff' is unknown or unusual in English nomenclature, and 'Hirst' or 'Hurst' belongs rather to Sussex and Kent than to Somerset. The fact is that the hill in old deeds is spelt 'Grobefast,' and is at this time colloquially 'Grabbist.' Near it is a lofty detached hill known as 'Conygaer,' crowned by a tower of the last century. At present it is thickly planted, but no camp has been discovered there, such as the name would indicate. The castle mill remains. It is placed on the verge of the park, upon the stream, and concealed and protected by the castle.

The castle is composed of two parts, due to the natural disposition of the ground; these are the tor or keep, and the lower ward. The tor is in form oval, and its summit, naturally flat, has been further levelled by art, as the slopes also have been trimmed, and rendered almost impracticable for direct ascent. The summit measures about 35 yards east and west by 70 yards north and south. The keep, which stood here, has disappeared, and its existence, long a matter of tradition, may now be deduced from a sewer and some foundations in the southwest corner laid open a few years ago. The present 
surface was laid down as a bowling green in the last century, and a summer-house constructed at the northeast corner, in which is a window in the Perpendicular style taken from some earlier structure.

The artificial scarping of the hill sides was confined to the upper 80 or 100 feet. At this level are two platforms or shelves, one, a small one, towards the south, the other much larger, also chiefly natural, towards the north, and which forms the lower ward. The lower ward is of a semilunar or semioval figure, the hollow side being formed and occupied by a portion of the skirts of the tor. It measures about 33 yards north and south by 126 yards east and west, and covers about half an acre of ground. The outer or convex edge, steep by rature, has been cut into a low cliff, supported by a retaining wall, which, with its flanking towers and superstructure of parapet, protected this ward. At the foot of this wall, part of which supports the present house, the slope recommences, and though now terraced by roads and paths, formerly descended unbroken to the base of the hill.

The keep was probably either circular or polygonal, approached as at Lincoln by a direct flight of steps from the lower ward. Its gateway seems to have been defended by a portcullis, as one is mentioned in the records, which could not have been in the earlier gateway or the later gatehouse. The buildings and inhabited part of the old castle were in the lower ward or its north-eastern quarter, upon the enceinte or curtain wall, and on the site, generally, of the present house. The wall was strengthened and flanked by half-round towers, of which the lower part of several remain incorporated into the later building and connected with fragments of wall, now a part of the house, and betrayed by their excessive thickness. One of these walls has a core of the natural red sandstone rock, enclosed in masonry, but traceable by an occasional exudation of dampness. The gateway of this ward remains between two of these flanking towers. It is $9 \mathrm{ft}$. broad, with plain chamfered jambs and a low stiff drop arch. There was no portcullis, and probably no drawbridge, the only defence being a door composed of bars of oak, 4 inches square and 4 inches apart, forming a grating, planked vertically outside with inch-and-a-half 
oak plank. Upon each oak bar was laid a bar of iron, and the whole fabric was spiked together with iron fastenings, having diamond-shaped heads. The meeting line of the two valves was guarded by an iron bar. In the right valve, on entering, is a wicket-gate $3 \mathrm{ft} .8 \mathrm{in}$. high by $2 \mathrm{ft}$. $6 \mathrm{in}$. broad, fastened with a huge iron lock in a wooden shell. This very curious specimen of carpenter's and smith's work, though of later date than the gateway, is old, not unlike that of Chepstow Castle, and probably of the time of Henry VIII or Elizabeth. The gateway itself belongs to those of Henry III or his son. In the last century the gates were permanently closed, and behind them was built a wall backed with earth. The gateway has recently been restored as far as possible to its original condition, and now gives access by steps to the lower ward.

The mural towers flanking the gateway are parts of circles, $16 \mathrm{ft}$. 6 in. external diameter, and the lower $12 \mathrm{ft}$. are original. One contains a curious vaulted basement with the usual three loops, and in the rear a doorway which opened into the ward. The other, or eastern flanker, had a basement chamber until recently filled with earth, and had also three loops, of which two are still visible outside. This tower was connected with a building in its rear, the foundations of which are original, and now form a part of the offices. Also upon the retaining wall, but about 20 yards beyond, and to the south west of the old gateway, is another similar flanking tower, of which the upper story remains, and a part of a doorway. This tower is open in the rear. The towers, curtain, and entrance gateway are, in substance, all of one date, and what ashlar remains is of good quality and well jointed. The superstructure has been renewed recently.

The approach to the castle was steep, as it still is, from the town up to the old gateway, to enter which the road made a sharp turn. Just below the gateway, upon this approach, has been built a gatehouse, which projects from and is connected with the curtain, being incorporated into the tower, flanking the old curtain on the west side. This structure, the great gatehouse, still remains perfect, and though evidently intended more for ornament than defence, makes a most appropriate approach to the castle, 
and gives to the whole structure much of a mediæval and something of a military character. This building is rectangular, $63 \mathrm{ft}$. broad by $23 \mathrm{ft}$. deep, and about $45 \mathrm{ft}$. high, sixty-two steps leading to its battlements. It is pierced by a passage $10 \mathrm{ft}$. 6 in. broad, having a plain pointed waggon vault, and at each end a not very highly pointed arch, with good moulded jambs continued round the head. There are no lodge doors opening into the archway, and neither portcullis nor drawbridge. The fronts are plain, save that the exterior has two flanking buttresses, and over the entrance is a rectangular panel containing nine coats of arms in three rows-one, four, and four. The interior front is flanked by two half hexagonal turrets, of which that at the outer end contains a well stair, entered from the outside by a small four centred doorway, and communicating with each floor, and with the battlements. The corresponding turret is built upon one of the old mural towers which flanked the gateway of the lower ward. It contains a small chamber, probably a gardrobe, on each floor. Against the outer end of the building are two buttresses, a large and small one, probably added to support the wall which then stood upon a steep slope and shewed signs of settlement. The gatehouse is of three stages. The basement, has a chamber on each side of the main passage, entered, one by the well stair, the other by an exterior door. That next the well stair is $14 \mathrm{ft} .6$ in. by $9 \mathrm{ft} .8 \mathrm{in}$, and has a window to the front. That on the other side of the archway is $21 \mathrm{ft}$. $6 \mathrm{in}$. by $16 \mathrm{ft} .3 \mathrm{in}$., and is entered from the outside by a small doorway, probably an insertion. Opening from this chamber are two closets, and a well stair ascends to the two floors above.

The first floor contains two rooms, $22 \mathrm{ft}$. $10 \mathrm{in.} \mathrm{by}$ $16 \mathrm{ft} .6 \mathrm{in}$, and $21 \mathrm{ft} .6$ in. by $16 \mathrm{ft} .6 \mathrm{in}$, and $13 \mathrm{ft}$. high. In its inner end are two closets.

The second, upper, or principal floor, was formerly of two rooms, but has recently been converted into a handsome hall, $47 \mathrm{ft}$. by $16 \mathrm{ft}$. 6 in., with an open roof. It has five windows and a fireplace, and is entered on the level from the lower ward by a doorway, which seems an insertion of the date of Henry VIII, and which has the head of the well stair on one side, and beyond, on each 
side, a closet. The windows of the gatehouse are mostly of two lights, divided by a transom into four, with the upper lights cinquefoiled and in the head quatrefoiled. The summit is embattled, and at the four angles are turrets, of which the two to the outer or front face are apparent only.

The shields on the exterior panel are, in the upper line, 1. Luttrell with crest and supporters. Below, in the next line, 2. Luttrell impaling Courtenay ; 3. Luttrell impaling Beaumont of Sherwell; 4. Luttrell impaling Audley; 5. Luttrell impaling Courtenay of Powderham. In the lower row, 6. Luttrell impaling Hill ; 7. Luttrell impaling blank ; 8 and 9 blank. The Luttrell supporters were two swans chained and collared, derived from Bohun through Courtenay. The date of this gatehouse is uncertain. It has been thought to be the "novum ædificium castri de Dunster," with the construction of which the accounts shew Henry Stone to have been charged in the 9 th of Henry $V$, but the lower part is of the style prevalent under Richard II. The door from the lower ward into the lobby is scarcely earlier than Henry VII or VIII.

It is probable that the gatehouse was for some time used in combination with the gateway by its side, until the latter was closed. The approach and entrance, however inconvenient, were strong, and almost precluded any regular attacks by battering machines or even by escalade.

The history of Dunster commences with Domesday, in which it is recorded that William de Mohun holds Torre, and there is his castle. Aluric held it in the time of King Edward. "Ipse [Willielmus de Moion] tenet Torre Ibi est castellum ejus. Aluric tenuit T.R.E." These words are very appropiately inserted over the great chimney piece in the hall. The Exeter Domesday also confirms the holding both of Mohun and Aluric. Who Aluric was is unknown. That he was a considerable Englishmen none can doubt, but the name was common, occurring sixty-four times in Domesday, as does Alric, probably the same name, twenty-six times.

Mohun no doubt found the tor strongly fortified, after the English manner, for not only was it a frontier fortress against the Celts beyond the Tamar, but it must have been exposed to the piratical invasion of the Northmen, 
who gave name to the opposite islands of the Holms, and the not very distant port of Swansea. The place was in fact a natural burh, on a large scale, such as Æthelflæd and Eadward the Elder were wont to throw up artificially on a smaller scale in the early part of the tenth century. There was the conical hill with its flat top for the aula or domus defensabitis, and the court yard below for the ìuts and sheds of the dependants and cattle.

William de Mohun was no mere adventurer. He was a great baron of the Cotentin, having the castle of Moion in la Mancha. He fought at Hastings with a knightly following, and received from the Conqueror from sixty to seventy manors in Somerset, Devon, Dorset, and Wilts. These manors were in his time or in that of his successor combined into an Honour, as was the case with those attached to the chief seats of Plympton, Totnes, and Barnstaple. Dunster became the caput honoris.

The Honour of Dunster was one of about eighty-six in England, though in what they differed from baronies is not precisely understood. The nucleus of either was almost always an estate held before the conquest, added to largely by the Norman who conquered it. In all cases it extended into more than one county, and was held of the king in capite by homage, fealty, and military service. By the laws of Henry I, every lord could summon his liegemen before the court, et si residens est ad remotius manerium ejusdem honoris unde tenet, ibit ad placitum, si dominus suus summoneat eum. The Honour is not a jurisdiction mentioned in Domesday, unless it be in a passage relating to Cornwall where it is recorded, Ho terro pertinent ad honores chei; chei being a place. The term is said to have been first used by the Conqueror in his charter to the Abbot of Ramsey. Most of the Honours seem to have fallen into disuse by the alienation of the manors composing them, as was the case with Dunster, although the records shew that for many centuries the rights were maintained by the lord of the castle in full rigour.

To what extent the Mohuns were content with the earlier defences of the castle is unknown, but it is remarkable that no mouldings or fragments of Norman ornament have been dug up in or about the building, 
althongh there is original Norman work in the parish church. From the configuration of the ground the lines of the old fortress must have been where they still are, so that there would be no reason for pulling down the earlier works to enlarge the area; and yet it is difficult to suppose that works as durable as was the case with those of the Norman period could have fallen to decay by the reigns of Henry III or Edward I, the date of the oldest extant parts. However this may be, it is certain that the castle of the Mohuns was one of the most important of the western fortresses ; and in the lawless days of Stephen it was held for the Empress against the King, during the great revolt of 1138 , its lord being then William de Mohun, the second baron.

William, indeed, was not content with passive resistance. He is described as the 'Scourge of the West,' ravaging and plundering the country up to the gates of Barnstaple, where he was held in check by Henry de Tracy. He is said to have been created earl either of Dorset or Somerset, or both, by the Empress in 1140; but this creation rests on very uncertain authority, and has never been admitted as valid. The earldoms of that period were very irregular, and some were afterwards set aside. This lord founded the Augustin Priory of Brewton, in Somerset, and, according to the Black Book of the Exchequer, he held forty-four knights' fees. It is not improbable that to him is due the circular or polygonal keep, which was common at that time where a castle possessed a mound, and which is known to have stood on the summit of the tor.

No mention of the castle occurs till the reign of John who held the castle and Honour during the minority of Lord Reginald, when the fines, \&c., for the Honour were levied by the King's officers. In the Chancery roll of 1201-2, Nicholas Puinz accounts for $15 s$. $2 \frac{1}{2} d$., half a year's pay allowed to the janitor of the castie, and the same to the watchman; and these payments are repeated by Reginald de Clifton, who in 1204 was ordered to place Reginald de Moyon in possession of the castle of Dunster and the heritage then in his custody. A very little before this, the coming of age of Reginald, Hubert de Burgh was in charge, and had accounted 'de finibus 
militum' of the Honour ; and 25th February, 1202, John called upon the knights and free tenants to contribute through De Burgh for strengthening the castle. 'Our castle,' the King calls it, probably not merely as holding it in wardship, but as asserting the general rights of the crown to all castles. A second Reginald seems to have founded a mass for the weal of his ancestors, to be said daily by a monk or a secular priest, to be provided by the Prior, in the upper or St. Stephen's chapel, in the castle, or during war in the chapel of St. Lawrence, within the Priory. If the same was neglected, power was reserved to distrain upon the goods of the Prior. Leland mentions St. Stephen's chapel as connected with the keep. There seems also to have been a second chapel, as usual, in the lower ward. Upon the death of Lord Reginald, about 1213, the Honour again fell into the hands of the crown during a long minority. Henry Fitz Count was placed in charge, and Alice the widow was allowed dower and 'maritagium.' It is curious that $\mathbf{J}$ ohn does not appear to have visited Dunster, although he was at Stoke-Courcy.

Henry III, in 1220, placed the forest of Dunster in charge of Peter de Maulay. He retained the castle in his own hands, and there occur several charges for the payment of Roger and William de Vilers, as "balistarii regis," who dwelt in the king's castle of Dunster. A specific order in 1222 places the Mohun lands in Carhampton in charge of William Briwer, probably next of kin to the widow, but reserves to the king's hands the castle and vill of Dunster. Soon after, Watchet market being unlicenced and injurious to Dunster was put down (Close Roll I. 137, 4] 8,605$)$. The above were not the only persons to whom from time to time this valuable wardship was committed.

Of the condition of the castle at the close of this wardship, nothing is on record; but the wealth of the family was much augmented by the match of Reginald, King John's ward, with a Briwer coheiress, and either his son Reginald, the founder, 1246, of Newenham Abbey, who died 41st Henry III, 1256, or his grandson John, who died 7 th Edward I, 1278, the last baron by tenure, might have built the curtain and mural towers containing the lower ward, of which the bases remain. The keep 
was probably left unaltered, and indeed from the great and inconvenient height at which it stood, could have been but little used. The purely defensive parts of castles, when not inhabited by the owner, were usually but little cared for, and the allowance for a porter and a single watchman shew that in this respect Dunster was no exception.

In 1376, John de Mohun, the eighth baron and the tenth in lineal descent from the founder of the family, died, leaving daughters only, and a sale of the castle and the rest of the property was effected by his widow Joan Burghersh. The purchaser was another widow, Elizabeth, daughter of Hugh Courtenay, Earl of Devon, and widow, first, of Sir John de Vere, and afterwards of Sir Andrew Luttrell of Chilton, a cadet of the barons Luttrell of Irnham. Elizabeth was a lady of high rank, of kin through the Bolnun's to Edward III, and with the command of great wealth. Her son, Sir Hugh Luttrell, became the new lord of the castle and Honour, and probably built the great gatehouse.

'The Luttrells were steady Lancastrians, and their representative, Sir James, took knighthood on the field of Wakefield, and fell in the second battle of St. Alban's, when his estates were confiscated 1st Edward IV, though only to be restored, 1st Henry VII, in the person of his son, Sir Hugh. Sir Hugh Luttrell stood high in the favour of Henry VII, and seems to have lived at Dunster in great splendour. To a second Sir Hugh, Leland attributes the great gatehouse, and he may have completed or repaired it, and opened its south door leading upon the lower ward. Probably he also inserted the armorial panels over the entrance portal, the last of which complete bears his coat impaling that of Margaret Hill, his wife. He also repaired the chapel of St. Stephen. Leland describes the donjon or keep as having been "full of goodly buildings," which, however, had disappeared even before his time. The inhabited part of the castle was then, as now, in the north-east angle of the lower ward. Sir Andrew, Sir Hugh's son and successor, "built a new piece of the castle wall by the east."

The next possessor who left his mark upon the castle was George Luttrell, Sheriff of Somerset in 1593. He 
built the market-house in the town and the older part of the present dwelling-house, which bears date 1589, incorporating with it much of the curtain wall, towers, and walls of the older and more distinctly military building. The entrance to the ward seems to have remained as before, through the gateway between the flanking towers.

During the wars between Charles and the Parliament, the Luttrells sided warmly with neither party, and were out of favour with both. Its owners at this time were Thomas Luttrell who died 1644, and George died 1655. In 1643 a royalist garison under Colonel Wyndham took possession, and the castle was visited by Prince Charles, whose chamber is still pointed out. In 1646 Blake laid siege to the castle for the Parliament, and battered it from the north west, behind the Luttrell arms. It was surrendered by Wyndham in April 1646. A few iron cannon balls, memorials of this siege, have been found.

The government, although they apologised for the military occupation of the castle, levied a local rate for pulling it down. Probably this referred only to the upper part of the curtain wall on either side of the gatehouse. It is said that the gatehouse was injured, but its present condition shows that the injury could not have been of a very serious character.

A century later the accounts show that the Luttrells raised the surface of the lower ward, probably about fourteen feet, evidently with earth obtained by scraping the adjacent slope of the tor. This, which involved the closing up of the old gateway, was probably combined with the construction of a new approach which passed below and outside of the gate house, wound round the castle and the tor, and entered the lower ward at the new level. Matters thus remained until the accession of Mr. George Luttrell in 1869, when under the judicious advice of Mr. Salvin, a great addition was made to the Elizabethan house, a new tower was constructed on the west front, and the foundation and pavements of buildings along the north front and connected with the entrance gate and the gatehouse were laid open, and the walls restored and rebuilt, and a terrace formed along a part of the curtain. The approach for carriages was also much 
improved, though, as before, at the cost of avoiding the great gate house.

The ancient walls incorporated with the later residence prove that there must have been very considerable buildings upon the ground now occupied by it, but there is some reason to suppose that both. hall and chapel stood near the site of the later gate house, and, therefore, to the right or west of the original entry. If this be so, the extent of buildings in the lower ward must have been very considerable indeed, as in the other direction they certainly extended, as does the present house, to the foot of the tor, and were flanked by it. Nevertheless, considerable as the alterations have been, and handsome and convenient as are the rooms of the present mansion, it represents very fairly the original fortress, and, like it, is sheltered by the tor, and predominates over the park, the town, and the seacoast, commanding a very extensive view, and, as becomes the representative of so important a military post, is itself visible from the tract of country of which it was sometimes the terror, but more frequently the protection. 